\title{
The influence of rock uplift rate on the formation and preservation of individual marine terraces during multiple sea-level stands
}

\author{
Luca C. Malatesta ${ }^{1,2,3}$, Noah J. Finnegan ${ }^{3}$, Kimberly L. Huppert ${ }^{1}$ and Emily I. Carreño ${ }^{3}$ \\ ${ }^{1}$ Earth Surface Process Modelling, GFZ German Research Center for Geosciences, 14473 Potsdam, Germany \\ 2Institute of Earth Surface Dynamics, University of Lausanne, 1015 Lausanne, Switzerland \\ 3Department of Earth and Planetary Sciences, University of California, Santa Cruz, California 95064, USA
}

\begin{abstract}
Marine terraces are a cornerstone for the study of paleo sea level and crustal deformation. Commonly, individual erosive marine terraces are attributed to unique sea-level high stands based on the reasoning that marine platforms could only be significantly widened at the beginning of an interglacial. However, this logic implies that wave erosion is insignificant at other times. We postulate that the erosion potential at a given bedrock elevation datum is proportional to the total duration of sea-level occupation at that datum. The total duration of sea-level occupation depends strongly on rock uplift rate. Certain rock uplift rates may promote the generation and preservation of particular terraces while others prevent them. For example, at rock uplift of $\sim 1.2 \mathrm{~mm} / \mathrm{yr}$, the Marine Isotope Stage (MIS) 5e (ca. $120 \mathrm{ka}$ ) high stand reoccupies the elevation of the MIS 6d-e mid-stand, favoring creation of a wider terrace than at higher or lower rock uplift rates. Thus, misidentification of terraces can occur if each terrace in a sequence is assumed to form uniquely at successive interglacial high stands and to reflect their relative elevations. Developing a graphical proxy for the entire erosion potential of sea-level history allows us to address creation and preservation biases at different rock uplift rates.
\end{abstract}

\section{INTRODUCTION}

Marine terraces are key landforms for the study of paleo sea level (e.g., Broecker et al., 1968; Chappell, 1974; Machida, 1975) and crustal deformation (e.g., Otuka, 1934; Ota and Yoshikawa, 1978; Lajoie, 1986; Armijo et al., 1996). Commonly, individual marine terraces created by bedrock erosion are interpreted to form during unique sea-level high stands. This one-to-one correspondence is typically assumed for two reasons. First, low-gradient, shallowwater marine platforms-which become marine terraces after a fall in relative sea level (sea level relative to a land-based datum, typically the difference between eustatic and rock uplift rates) should grow faster through wave erosion when relative sea-level rise is very slow, such as at the beginning of an interglacial (see Bradley [1958] for a review of early $20^{\text {th }}$ century literature). Second, the large eustatic sea-level drops that typically follow high stands can abandon and preserve marine terraces.
Using that conceptual model, Yoshikawa et al. (1964) identified the rock uplift rate that best projected relative sea-level high stands to the elevations of marine terraces observed around Tosa Bay, Japan (see the English translation of Yoshikawa et al. [1964] in the Supplemental Material ${ }^{1}$ ), which was perhaps the first documented attempt to quantify rock uplift rates by combining coastal morphology and a relative sea-level curve. Later, Lajoie (1986) merged this work with studies on constructional coral reef terraces (e.g., Broecker et al., 1968; Chappell, 1974) and declared that "a general consensus has developed" (Lajoie, 1986, p. 100) linking strandlines and high stands on rising coastlines. This morphostratigraphic approach relies on a bijective assumption that each individual terrace has a unique age linked to a unique high stand (Pastier et al., 2019), and it is commonly employed at sites where independent dating of terraces is scarce or infeasible.
Greater scrutiny, however, reveals that individual terraces can form and be reoccupied during multiple sea-level stands. Dufaure and Zamanis (1980) noted diachronous erosive terraces in the Gulf of Corinth, Greece, where three distinct terraces, separated by cliffs $>10 \mathrm{~m}$ high, merge into one as rock uplift rate decreases alongshore. In northern California (USA), Merritts and Bull (1989) explored how the relative heights of high stands contribute to preservation, reoccupation, or destruction of terraces as a function rock uplift rate. Armijo et al. (1996), also in Corinth, suggested that repeated occupation of a platform by successive high stands can lead to complex terrace structures and the absence of specific high stands from the record.

The observation of composite ages on individual coral reef terraces (e.g., Bard et al., 1996) and the occasional absence of specific Marine Isotope Stage (MIS) high stands in extensive coral terrace series (e.g., Pedoja et al., 2018) also calls into question the bijective rationale. Pastier et al. (2019) highlighted that a sea-level curve cannot be straightforwardly related to a coral reef terrace record because some terrace sequences may lack certain high stands and/or preserve steps that formed at lower sea-level stands.

Here, we question the default assumption that marine terraces can be uniquely linked to a sea-level high stand, and highlight how these terraces can be created by the integrated effects of successive episodes of wave erosion during multiple marine occupations of the same uplifting platform. To do this, we examine altitudinal transects of sea-level occupation under varying uplift conditions and identify the uplift rates that should enhance or reduce the potential for the generation and preservation of

${ }^{1}$ Supplemental Material. Additional figures, Video S1, a description of the code with a link to its repository, and an English translation of Yoshikawa et al. (1964) paper. Please visit https://doi.org/10.1130/GEOL.S.16624543 to access the supplemental material, and contact editing@geosociety.org with any questions.

CITATION: Malatesta, L.C., et al., 2021, The influence of rock uplift rate on the formation and preservation of individual marine terraces during multiple sea-level stands: Geology, v. 50, p. 101-105, https://doi.org/10.1130/G49245.1 


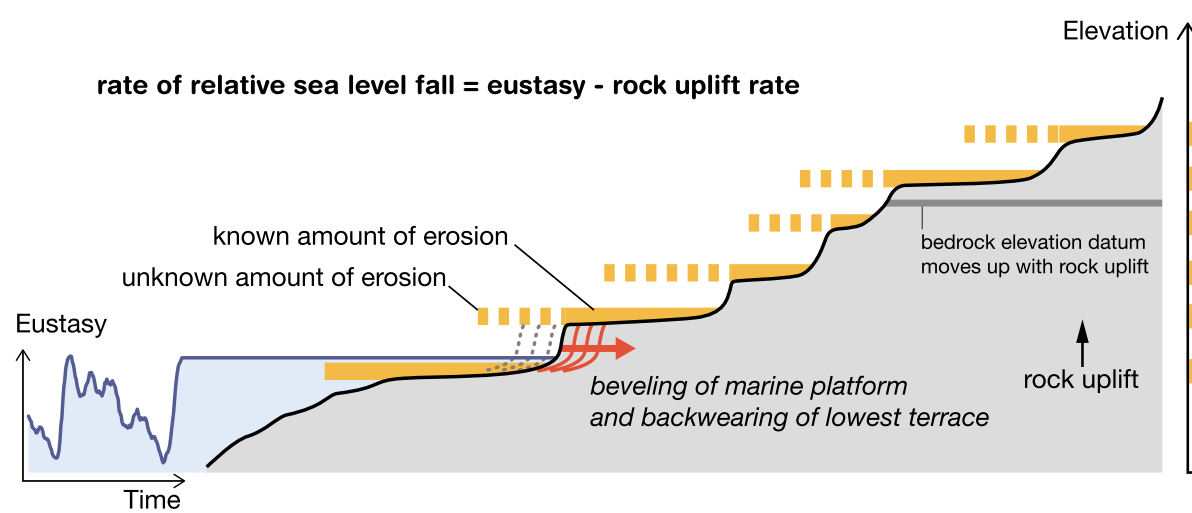

erosional terraces. Using a compilation of uplift rates inferred from marine terraces on convergent margins, we then consider the biases that polygenetic terraces can introduce into relative sea-level reconstructions and crustal deformation models.

\section{CREATION AND PRESERVATION OF MARINE TERRACES}

Bedrock sea cliffs erode by weathering, mass wasting, and various processes driven by wave attack. Because waves can impact and strain sea cliffs and mobilize sediment (Adams et al., 2005; Trenhaile 2019), sea cliff erosion rates increase with wave energy flux in a range of environments over annual to million-year time scales (e.g., Alessio and Keller, 2020; Huppert et al., 2020; Young et al., 2021). Sea cliffs are thus expected to retreat farther inland and etch a wider shallow-water platform when they are exposed to wave action for a longer period of time. This progressive widening should occur even if wave energy dissipanedy et al., 2011). tion across an increasingly wide shelf reduces rates of sea cliff retreat and further platform widening (Anderson et al., 1999). The resulting shallow-water platform can be further abraded by sediment moved by shallow-water waves (Bradley and Griggs, 1976) and/or by weathering processes in the intertidal zone (e.g., Ken-

Sustained and/or recurrent wave erosion at a given bedrock elevation datum (i.e., horizontal strip of bedrock in the frame of reference of uplifting rock) should promote the creation of a wide, low-gradient platform that would likely remain identifiable as a marine terrace on an uplifting coastline. The potential to generate an identifiable terrace therefore grows with the amount of time sea level spends at a given bedrock elevation datum. On the other hand, marine terraces can also be effectively erased from the chronostratigraphic record if a subsequent sealevel stand occupies and erodes the same bedrock datum (resetting its age). The preservation potential of a terrace can also decrease with the

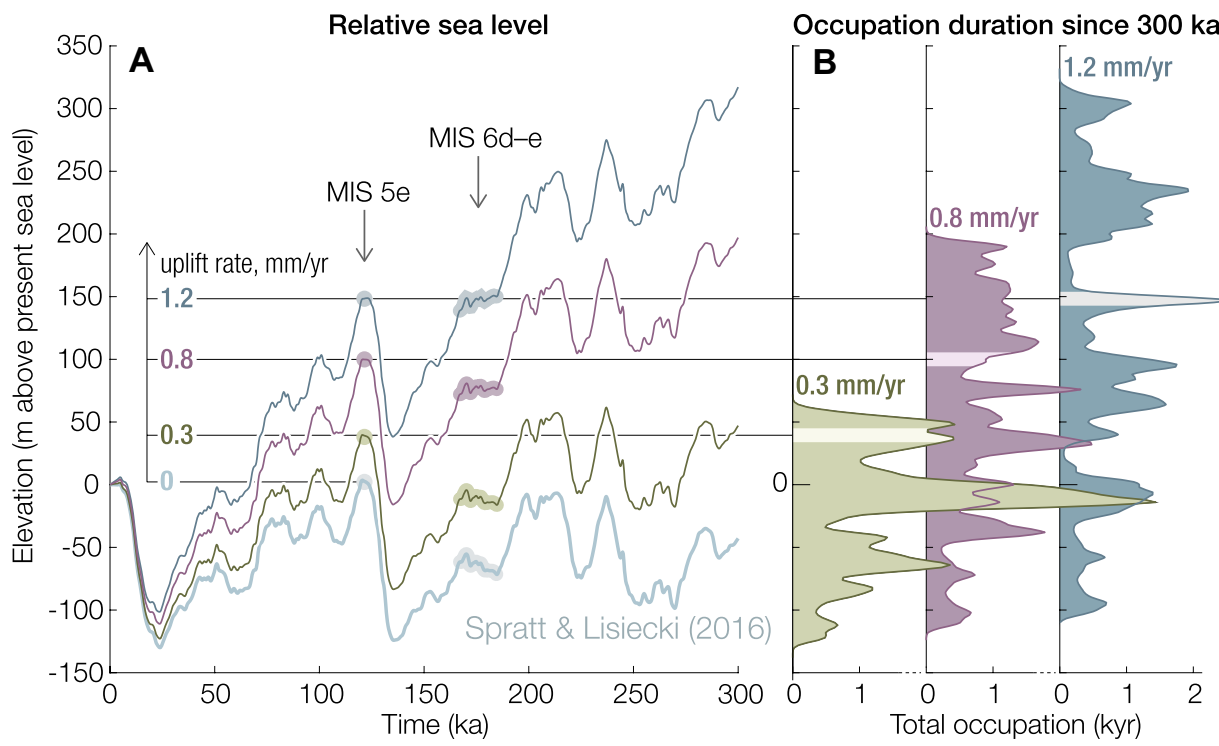

Figure 2. (A) Time series of relative sea level and (B) cumulative sea-level occupation of bedrock elevations for coastlines uplifting at $0.3,0.8$, and $1.2 \mathrm{~mm} / \mathrm{yr}$ since $300 \mathrm{ka}$. Horizontal lines mark the present-day elevations of the Marine Isotope Stage (MIS) $5 e$ shoreline. The density functions are made with a kernel function using a $3 \mathrm{~m}$ bandwidth. Video $\mathrm{S} 1$ in the Supplemental Material (see footnote 1) may be useful for grasping the correspondence between A and B. known unknown

amount amount of work

of work (eroded away)

a

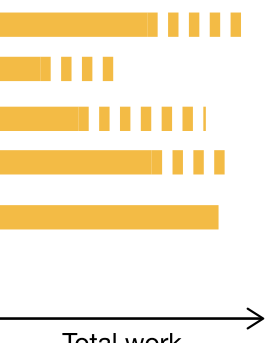

Figure 1. The steps of a terraced coastal landscape (left) record various amount of work expended by waves at different bedrock elevations (right) to bevel marine platforms that have become terraces (yellow bars) and have back-worn the terrace lying above. amount of time sea level spends at elevations closely below it, where subsequent erosion can undercut and destroy the abandoned platform.

If marine terraces are only created during periods of slow relative sea-level rise preceding high stands, as was initially surmised (Bradley, 1958), bedrock coasts would seemingly sit unchanged over the vast majority of their evolution and erode for only a few millennia every hundred thousand years or so. Waves still impact coasts throughout the glacio-eustatic sea-level cycle, however, so erosive potential persists even if it is modulated by changing wave energy, lithology, or sediment cover. We therefore postulate that, if marine platforms are formed by wave erosion and preserved intact, their widths should increase with the total amount of time sea level spends at that bedrock elevation datum, but this does not have to be during a continuous time span (Fig. 1).

\section{SEA-LEVEL OCCUPATION AS A FUNCTION OF UPLIFT}

To represent the work of wave erosion on the coastline, it is practical to use the reference frame of the uplifting bedrock (Fig. 2A). In Figure 2, we show the elevations of past eustatic sea levels relative to present sea level (Spratt and Lisiecki, 2016) if those past sea levels are uplifted at rates of $0 \mathrm{~mm} / \mathrm{yr}, 0.3 \mathrm{~mm} / \mathrm{yr}, 0.8 \mathrm{~mm} /$ $\mathrm{yr}$, and $1.2 \mathrm{~mm} / \mathrm{yr}$. Relative sea level can be summed to determine the total amount of time spent at different bedrock elevation datums relative to present sea level (Fig. 2B; Walker et al., 2016; Jara-Muñoz et al., 2017). We display sealevel change since $300 \mathrm{ka}$ to focus on the periods preceding and following the last interglacial. From Figure 2, we note that elevations of longer sea-level occupation do not necessarily coincide with elevations of interglacial high stands. Coastlines uplifting at $0.3 \mathrm{~mm} / \mathrm{yr}$ and $1.2 \mathrm{~mm} / \mathrm{yr}$ experience long durations of sea-level occupation at the elevation of MIS 5e over the past 300 k.y., whereas sea-level occupation at that elevation is much shorter on coastlines experiencing rock uplift of $0.8 \mathrm{~mm} / \mathrm{yr}$.

The distributions of total sea-level occupation (Fig. 2B) are shown by color brightness 
along a continuous spectrum of uplift rates in Figure 3 (plot since $600 \mathrm{ka}$, alternative sealevel curves; the Python scripts needed for Figures 2 and 3 are provided in the Supplemental Material). For instance, in examining the color brightness along a vertical transect at an uplift rate of $0.8 \mathrm{~mm} / \mathrm{yr}$, we see the longest occupation (darkest color) at $\sim 40 \mathrm{~m}$ above present sea level (masl). The uplifted elevations of individual high stands are represented with dashed lines, and these do not necessarily match peaks in occupation (e.g., either side of the MIS 7e line in Fig. 3). The slope of a high-stand dashed line is proportional to its age. Instances of repeated occupation are apparent at numerous other rates of uplift, which makes clear that a bijective interpretation of marine terrace morphostratigraphy is invalid in a wide range of tectonic settings.

An additional source of error may arise when a terrace is resubmerged by a subsequent high stand and draped with coral or sediment of that younger age. For example, at $0.8 \mathrm{~mm} / \mathrm{yr}$, a terrace generated at MIS $6 \mathrm{e}(\sim-60 \mathrm{masl})$ would be uplifted to $\sim 80$ masl (Figs. $2 \mathrm{~A}$ and 3 ), which is $<20$ m below the elevation of MIS 5e occupation. If MIS 5e deposited coral or sediment on this terrace, the attribution of an MIS 5e age to this older, lower platform would yield an apparent rock uplift of only $0.67 \mathrm{~mm} / \mathrm{yr}$. Similarly, corals were deposited at ca. $100 \mathrm{ka}$ on a resubmerged ca. 120 ka terrace on San Nicolas Island, in the Channel Islands of California, which resulted in a mismatch between the ages of carbonate deposition and platform erosion at a true rock uplift of $\sim 0.25-0.27 \mathrm{~mm} / \mathrm{yr}$ (Muhs et al., 2012). This potential for age-platform mismatch can be tracked across a spectrum of uplift rates in Figure 3 by comparing the elevations of high stands and those of long sea-level occupation.

\section{EVIDENCE AT GLOBAL AND LOCAL SCALES}

A global compilation of presumed MIS 5e marine terrace ages and elevations (Pedoja et al., 2014) suggests that time-averaged rock uplift rates at convergent margins since MIS 5e cluster around a primary peak at $0.2-0.3 \mathrm{~mm} / \mathrm{yr}$ and a secondary peak around $0.9 \mathrm{~mm} / \mathrm{yr}$ (Fig. 4A). We calculated these uplift rates assuming a globally consistent MIS 5e sea level equivalent to that of the present. Individual regions included in the compilation show similar bimodality (Fig. 4B). We failed to identify a geological process that would explain an abundance of uplift rates between 0.8 and $1.1 \mathrm{~mm} / \mathrm{yr}$ or a lower representation around $0.6 \mathrm{~mm} / \mathrm{yr}$.

We suggest that this bimodality in apparent rock uplift rates may arise from a propensity for rock uplift rates of $\sim 0.9-1.2 \mathrm{~mm} / \mathrm{yr}$ to favor the creation and preservation of MIS $5 \mathrm{e}$ terraces. MIS 5e sea levels reoccupy the same bedrock elevation as MIS 6d-MIS 6e for uplift rates of $\sim 0.9-1.2 \mathrm{~mm} / \mathrm{yr}$ (Figs. 2 and 3 ). This leads to a significantly longer total duration of occupation at MIS 5e elevation at these rock uplift rates (creation potential) as well as only a brief occupation below it (destruction potential; Fig. 4C). A MIS 5e terrace on a coastline uplifting at $0.9-1.2 \mathrm{~mm} / \mathrm{yr}$ may be wider and more easily identifiable, which could lead to a further sampling bias. This may explain the overrepresentation of these rock uplift rates in the global marine terrace record. The range and distribution of rock uplift rates that can be inferred from the marine terrace record is biased by the considerable influence that rock uplift rates exert on the duration of sea-level occupation at a given bedrock datum.

The coast around Santa Cruz, California, is characterized by an $\sim 10-\mathrm{km}$-wide, $<125$-m-deep, erosive marine platform (Figs. 4D and $4 \mathrm{E}$ ). Rock uplift rates vary along the coast and may be as high as $\sim 1 \mathrm{~mm} / \mathrm{yr}$ (Perg et al., 2001 ) but generally cluster around $\sim 0.4 \mathrm{~mm} /$ yr (Bradley and Griggs, 1976; Anderson, 1990; Valensise and Ward, 1991; Gudmunsdottir et al., 2013). At $0.4 \mathrm{~mm} / \mathrm{yr}$, several episodes of sealevel occupation align near or below modern sea level (Figs. 2 and 3). Accordingly, we expect a large platform carved by repeated long-term sea-level occupation and wave erosion at and below sea level as is observed in the bathymetry (Figs. 4D and 4E).

\section{DISCUSSION}

Some complications and pitfalls in inferring rock uplift rates from marine terraces have previously been identified (e.g., Armijo et al., 1996). Here, we seek to move past a cautionary tale and propose a strategy for quantifying this source of bias and better exploiting the topographic record. At this stage, we cannot prove the hypothesis that marine terraces depend more on total sea-level occupation than

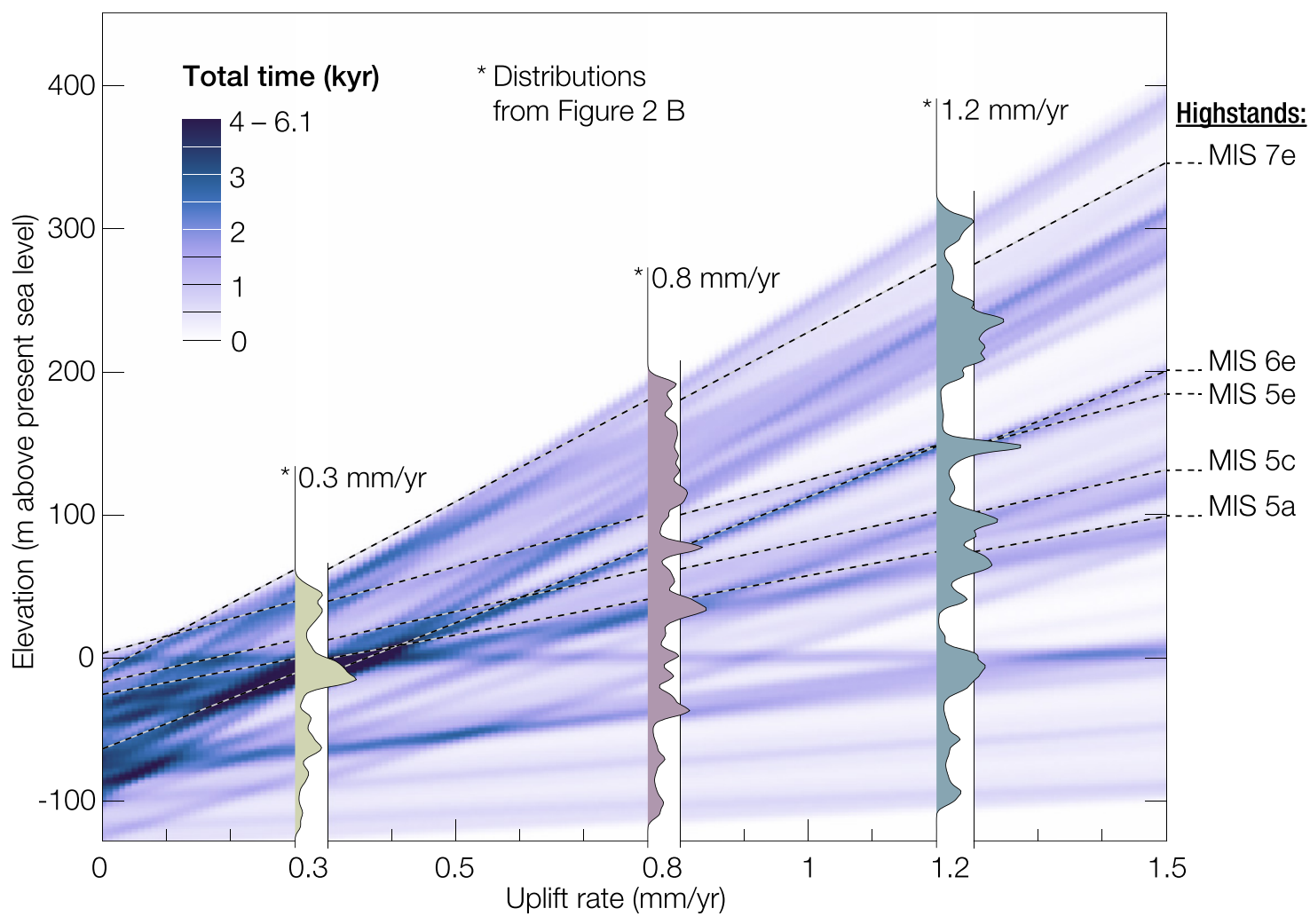

Figure 3. Duration of sea-level occupation of bedrock datums since $300 \mathrm{ka}$ as a function of rock uplift rate displayed by color brightness, with distributions of relative sea-level occupation from Figure 2B shown for select uplift rates. Dashed lines show the present-day elevation of specific Marine Isotope Stage (MIS) stages across all uplift rates. Sea-level data are from Spratt and Lisiecki (2016). 

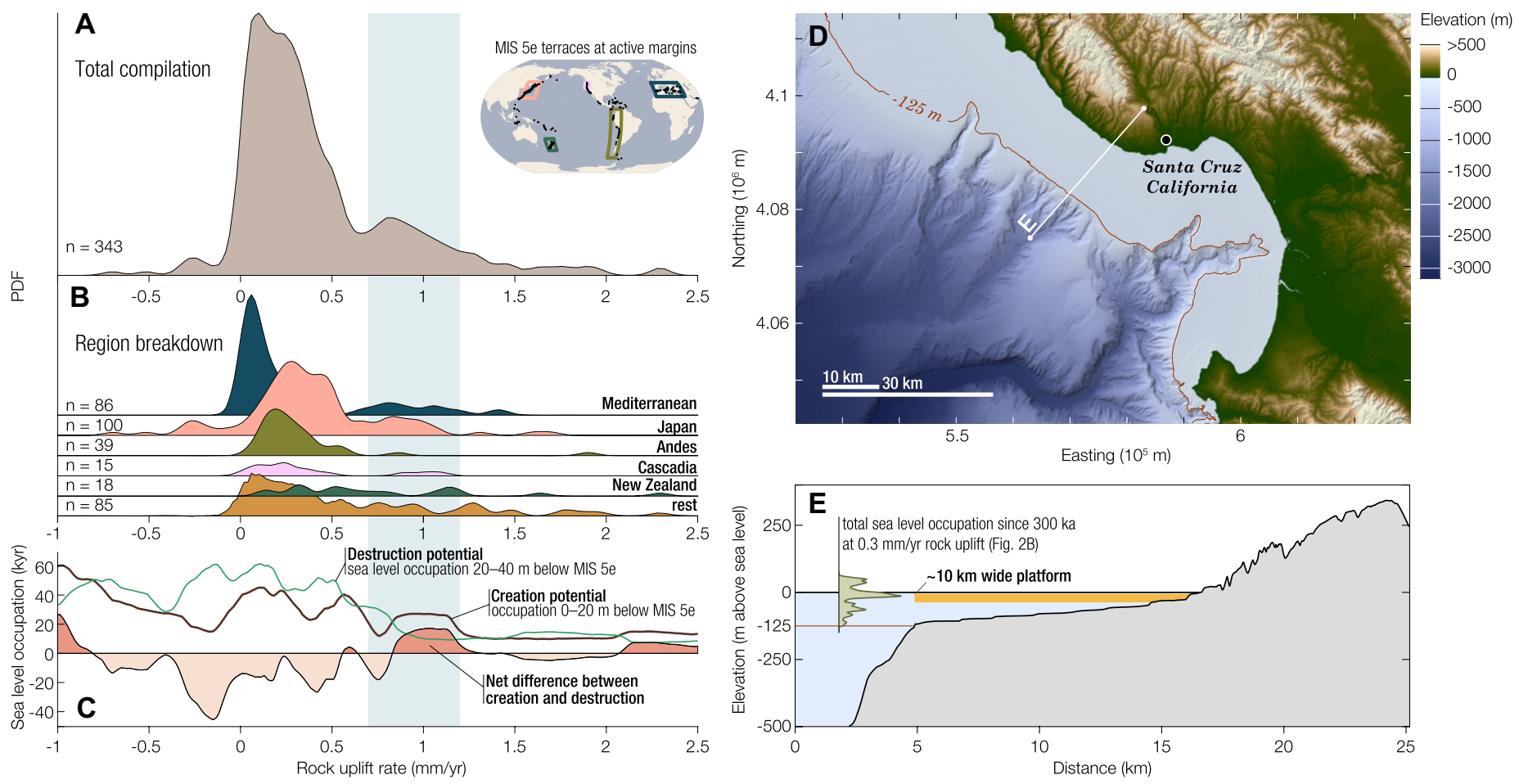

Figure 4. (A) Total distribution of uplift rates at convergent margins around the globe is shown (Pedoja et al., 2014). MIS-Marine Isotope Stage. (B) Distribution of uplift rates at the six sub-sites comprising A. (C) Total sea-level occupation at the elevation of the 5e terrace and immediately below (using $20 \mathrm{~m}$ windows) and the net difference between the potential for creation and destruction they represent (sea-level data are from Spratt and Lisiecki, 2016). (D, E) Topography and profile (white line) of the Santa Cruz and Monterey Bay area (Ryan et al., 2009).

on individual high stands. Two tests, however, could be employed: (1) differentiating ages of platform formation and coral or sediment cover, and (2) surveying the age and geometry of a continuous terrace across a gradient in rock uplift rate.

The first test would identify episodes of reoccupation of wider terraces by subsequent high stands based on observations of a difference between platform age and (multiple) sediment and/or coral cover age(s). Independently constrained rock uplift rates, e.g., from fluvial terraces or denudation rates, can guide the choice of ideal survey sites to target potential reoccupation episodes such as those that are expected to occur on coasts uplifting at $0.8 \mathrm{~mm} /$ yr (Fig. 3).

For the second test, it may be productive to investigate the geometry and surface age of terraces that increase in elevation along a coastline due to a gradient in rock uplift rates. Such terraces may provide evidence of reoccupation dependent on rock uplift rate. For example, at rock uplift rates of $<1.2 \mathrm{~mm} / \mathrm{yr}$, a terrace carved during the mid-stand period MIS 6d-e would show evidence of reoccupation during MIS $5 \mathrm{e}$ while at rock uplift rates $>1.2 \mathrm{~mm} / \mathrm{yr}$, the youngest sediment ages on the same terrace would be MIS 6d-e (Fig. 3).

Here, we used a global benthic oxygen isotope-based eustatic sea-level curve, but our graphical solution can easily be applied to alternative sea-level curves; e.g., at high latitudes where the gravitational component of glacial isostatic adjustment differs significantly from global averages (Mitrovica et al., 2001; Simms et al., 2016).

\section{CONCLUSIONS}

Marine terraces provide a direct means of constraining the magnitude and timing of past sea level and solid earth deformation. Sequences of drowned or uplifted marine terraces are often interpreted to have formed at successive interstadials; each terrace relates uniquely to a past high-stand sea level. Yet, this record can be affected by the repeated occupation of specific bedrock datums by sea level. The nonlinear scaling of rock uplift rates and the durations of sea-level occupations (arising from the recombination of complex sea-level curves) may promote or hinder the creation and preservation of marine terraces at various elevations in different tectonic settings. This may explain both an apparent overrepresentation of rock uplift rates between $0.8 \mathrm{~mm} / \mathrm{yr}$ and $1.2 \mathrm{~mm} / \mathrm{yr}$ inferred from the global marine terrace record and the $>10 \mathrm{~km}$ width of the marine platform uplifting at ca. $0.4 \mathrm{~mm} / \mathrm{yr}$ off the coast of Santa Cruz, California. Representing the distribution of sea-level occupation time over a range of rock uplift rates illustrates the likelihood for marine terrace creation and the potential for bias in the record, which improves the quality and reliability of morphostratigraphic analyses.

\section{ACKNOWLEDGMENTS}

We thank Shigeru Sueoka and Sumiko Tsukamoto for support translating Yoshikawa et al. (1964), and Anne-Morwenn Pastier and Alessio Rovere for fruitful discussions. We thank editor Gerald Dickens, as well as Robert Anderson and two other reviewers for their help. L.C. Malatesta was supported by a Swiss National Science Foundation Postdoc Mobility Fellowship at the University of California, Santa Cruz (P2SKP2 168328).

\section{REFERENCES CITED}

Adams, P.N., Storlazzi, C.D., and Anderson, R.S., 2005, Nearshore wave-induced cyclical flexing of sea cliffs: Journal of Geophysical Research: Earth Surface, v. 110, F02002, https:// doi.org/10.1029/2004JF000217.

Alessio, P., Keller, E.A., 2020, Short-term patterns and processes of coastal cliff erosion in Santa Barbara, California: Geomorphology, v. 353, no. 106994, https://doi.org/10.1016/j.geomorph.2019.106994

Anderson, R.S., 1990, Evolution of the northern Santa Cruz Mountains by advection of crust past a San Andreas Fault bend: Science, v. 249, p. 397-401, https://doi.org/10.1126/science.249.4967.397.

Anderson, R.S., Densmore, A.L., and Ellis, M.A., 1999, The generation and degradation of marine terraces: Basin Research, v. 11, p. 7-19, https:// doi.org/10.1046/j.1365-2117.1999.00085.x.

Armijo, R., Meyer, B.G.C.P., King, G.C.P., Rigo, A., and Papanastassiou, D., 1996, Quaternary evolution of the Corinth Rift and its implications for the Late Cenozoic evolution of the Aegean: Geophysical Journal International, v. 126, p. 11-53, https:// doi.org/10.1111/j.1365-246X.1996.tb05264.x.

Bard, E., et al., 1996, Pleistocene sea levels and tectonic uplift based on dating of corals from Sumba Island, Indonesia: Geophysical Research Letters, v. 23, p. 1473-1476, https://doi .org/10.1029/96GL01279. 
Bradley, W.C., 1958, Submarine abrasion and wave-cut platforms: Geological Society of America Bulletin, v. 69, p. 967-974, https://doi.org/10.1130/00167606(1958)69[967:SAAWP]2.0.CO;2.

Bradley, W.C., and Griggs, G.B., 1976, Form, genesis, and deformation of central California wave-cut platforms: Geological Society of America Bulletin, v. 87, p. 433-449, https://doi .org/10.1130/0016-7606(1976)87<433:FGAD OC> 2.0.CO;2.

Broecker, W., Thurber, D.L., Goddard, J., Ku, T.-L., Matthews, R.K., and Mesolella, K.J., 1968, Milankovitch hypothesis supported by precise dating of coral reefs and deep-sea sediments: Science, v. 159, p. 297-300, https://doi.org/10.1126/ science.159.3812.297.

Chappell, J., 1974, Geology of coral terraces, Huon Peninsula, New Guinea: A study of Quaternary tectonic movements and sea-level changes: Geological Society of America Bulletin, v. 85, p. 553570 , https://doi.org/10.1130/00167606(1974)85<553:GOCTHP $>2.0$. CO; 2.

Dufaure, J.J., and Zamanis, A., 1980, Styles néotectoniques et étagements de niveaux marins sur un segment d'arc insulaire, le Péloponnèse, in Proc. Conf. Niveaux Marins et Tectonique Quaternaire dans l'Aire Méditerranéenne: Paris, Centre national de la recherche scientifique, p. 77-107.

Gudmundsdottir, M.H., Blisniuk, K., Ebert, Y., Levine, N.M., Rood, D.H., Wilson, A., and Hilley, G.E., 2013, Restraining bend tectonics in the Santa Cruz Mountains, California, imaged using ${ }^{10} \mathrm{Be}$ concentrations in river sands: Geology, v. 41, p. 843-846, https://doi.org/10.1130/ G33970.1.

Huppert, K.L., Perron, J.T., and Ashton, A.D., 2020, The influence of wave power on bedrock seacliff erosion in the Hawaiian Islands: Geology, v. 48, p. 499-503, https://doi.org/10.1130/ G47113.1.

Jara-Muñoz, J., Melnick, D., Zambrano, P., Rietbrock, A., González, J., Argandoña, B., and Strecker, M.R., 2017, Quantifying offshore fore-arc deformation and splay-fault slip using drowned Pleistocene shorelines, Arauco Bay, Chile: Journal of Geophysical Research: Solid Earth, v. 122, p. 4529-4558, https://doi .org/10.1002/2016JB013339.

Kennedy, D.M., Paulik, R., and Dickson, M.E., 2011, Subaerial weathering versus wave processes in shore platform development: Reappraising the Old Hat Island evidence: Earth Surface Processes and Landforms, v. 36, p. 686-694, https://doi .org/10.1002/esp.2092.
Lajoie, K.R., 1986, Coastal tectonics, in Press, N.A. ed., Active Tectonics: Washington D.C., National Academic Press, p. 95-124.

Machida, H., 1975, Pleistocene sea level of South Kanto, Japan, analysed by tephrochronology, in Suggate, R.P., and Cresswell, M.M., eds., Quaternary Studies: Royal Society of New Zealand Bulletin, p. 215-222.

Merritts, D., and Bull, W.B., 1989, Interpreting Quaternary uplift rates at the Mendocino triple junction, northern California, from uplifted marine terraces: Geology, v. 17, p. 1020-1024, https:// doi.org/10.1130/0091-7613(1989)017<1020:IQ URAT $>2.3 . \mathrm{CO} ; 2$

Mitrovica, J., Tamisiea, M., Davis, J., and Milne, G.A., 2001, Recent mass balance of polar ice sheets inferred from patterns of global sea-level change: Nature, v. 409, p. 1026-1029, https://doi .org/10.1038/35059054.

Muhs, D.R., Simmons, K.R., Schumann, R.R., Groves, L.T., Mitrovica, J.X., and Laurel, D., 2012, Sealevel history during the Last Interglacial complex on San Nicolas Island, California: Implications for glacial isostatic adjustment processes, paleozoogeography and tectonics: Quaternary Science Reviews, v. 37, p. 1-25, https://doi.org/10.1016/ j.quascirev.2012.01.010.

Ota, Y., and Yoshikawa, T., 1978, Regional characteristics and their geodynamic implications of late Quaternary tectonic movement deduced from deformed former shorelines in Japan: Journal of Physics of the Earth, v. 26, Supplement, p. S379S389, https://doi.org/10.4294/jpe1952.26.Supplement_S379.

Otuka, Y., 1934, Marine Pleistocene terraces near Kusiro, Hokkaido: Bulletin of the Earthquake Research Institute, Tokyo Imperial University, v. 12 , p. $798-803$.

Pastier, A.-M., Husson, L., Pedoja, K., Bézos, A. Authemayou, C., Arias-Ruiz, C., and Cahyarini, S.Y., 2019, Genesis and architecture of sequences of Quaternary coral reef terraces: Insights from numerical models: Geochemistry Geophysics Geosystems, v. 20, p. 4248-4272, https://doi .org/10.1029/2019GC008239.

Pedoja, K., et al., 2014, Coastal staircase sequences reflecting sea-level oscillations and tectonic uplift during the Quaternary and Neogene: EarthScience Reviews, v. 132, p. 13-38, https://doi .org/10.1016/j.earscirev.2014.01.007.

Pedoja, K., et al., 2018, On the long-lasting sequences of coral reef terraces from SE Sulawesi (Indonesia): Distribution, formation, and global significance: Quaternary Science Re- views, v. 188, p. 37-57, https://doi.org/10.1016/ j.quascirev.2018.03.033.

Perg, L.A., Anderson, R.S., and Finkel, R.C., 2001, Use of a new ${ }^{10} \mathrm{Be}$ and ${ }^{26} \mathrm{Al}$ inventory method to date marine terraces, Santa Cruz, California, USA: Geology, v. 29, p. 879-882, https://doi org/10.1130/0091-7613(2001)029<0879:UOA $\mathrm{NBA}>2.0 . \mathrm{CO} ; 2$.

Ryan, W.B.F., et al., 2009, Global Multi-Resolution Topography (GMRT) synthesis data set: Geochemistry Geophysics Geosystems, v. 10, Q03014, https://doi.org/10.1029/ 2008 GC002332.

Simms, A.R., Rouby, H., and Lambeck, K., 2016, Marine terraces and rates of vertical tectonic motion: The importance of glacio-isostatic adjustment along the Pacific coast of central North America: Geological Society of America Bulletin, v. 128, p. 81-93, https://doi.org/10.1130/ B31299.1.

Spratt, R.M., and Lisiecki, L.E., 2016, A Late Pleistocene sea level stack: Climate of the Past, v. 12, p. 1079-1092, https://doi .org/10.5194/cp-12-1079-2016.

Trenhaile, A.S., 2019, Hard-rock coastal modelling: Past practice and future prospects in a changing world: Journal of Marine Science and Engineering, v. 7, p. 34, https://doi.org/10.3390/ jmse7020034.

Valensise, G., and Ward, S.N., 1991, Long-term uplift of the Santa Cruz coastline in response to repeated earthquakes along the San Andreas fault: Bulletin of the Seismological Society of America, v. 81, p. 1694-1704.

Walker, R., Telfer, M., Kahle, R., Dee, M.W., Kahle, B., Schwenninger, J.-L., Sloan, R.-A., and Watts, A.B., 2016, Rapid mantle-driven uplift along the Angolan margin in the late Quaternary: Nature Geoscience, v. 9, p. 909-914, https://doi .org/10.1038/ngeo 2835 .

Yoshikawa, T., Sōhei, K., Ota, Y., 1964, Mode of crustal movement in the late Quaternary on the southeast coast of Shikoku, southwestern Japan: Geographical Review of Japan, v. 37, no. 12 , p. 627-648, https://doi.org/10.4157/ grj.37.627 (in Japanese).

Young, A.P., Guza, R.T., Matsumoto, H., Merrifield, M.A., O'Reilly, W.C., and Swirad, Z.M., 2021, Three years of weekly observations of coastal cliff erosion by waves and rainfall: Geomorphology, v. 375, 107545, https://doi.org/10.1016/ j.geomorph.2020.107545.

Printed in USA 